\title{
Analisis Fonetik Segmentasi terhadap Inteligibilitas Pengucapan Bahasa Inggris Guru Bahasa Inggris Non-Penutur Asing
}

\section{A Segmental-phonetic Analysis into Non-native English Teachers' Intelligibility of English Pronunciation}

\author{
Andre Anugrah*, Dadang Sudana, \& Yanty Wirza \\ Universitas Pendidikan Indonesia, Bandung, Jawa Barat, Indonesia \\ andreanugrah0103@gmail.com*
}

Naskah diterima tanggal 25/08/2020, direvisi akhir tanggal 25/12/2020, disetujui tanggal 31/12/2020

\begin{abstract}
Abstrak
Analisis fonetik segmentasi ini bertujuan untuk mengetahui seberapa jelas pelafalan bahasa inggris guru bahasa inggris non-pentur asli dalam mengartikulasi bunyi-bunyi fonemik terkait fonetik segmentasi. Penelitian ini merupakan penelitian deskriptif kualitatif dengan 3 partisipan yang dipilih secara sengaja berdasarkan beberapa kriteria yang telah ditetapkan. Pengumpulan data dilakukan dengan dua jenis instrumen yaitu PIT (Tes kejelasan pengucapan) dan tes sejenis IELTS. Analisis data dilakukan dengan menggunakan penjelasan fonetik berbasis kesalahan. Temuan mengungkapkan bahwa dalam hal performa segmental, semua peserta memiliki inteligibilitas pengucapan yang tidak memadai dikarenakan banyaknya ditemukan distorsi beberapa konsonan seperti frikatif (dental, labio-dental, alveolar, dan palato-alveolar), dan juga fonemik vokal seperti vokal terbuka dan vokal dekat. Analisis ataupun kajian tentang artikulasi fonemik (segmental) amat sangat dibutuhkan bagi semua orang yang berbahasa inggris baik dari kalangan masyarakat umum, pelajar, terlebih lagi pengajar dikarenakan faktor pencentus utama unintelligible pronunciation (pengucapan yang tidak dipahami) adalah jumlah kesalahan pada artikulasi (produksi) fonemik dari kelas konsonan dan vokal.
\end{abstract}

Kata kunci: Inteligibilitas; Fonetik; Pengucapan; Segmentasi.

\begin{abstract}
This segmental-phonetic inquiry was conducted to find out how intelligible select-nonnative English speakers speak English in regard to phonetic segmental. This research was a qualitative descriptive study with 3 participants selected purposefully based upon some established criteria. The data were collected by means of two kinds of instruments, namely PIT (Pronunciation intelligibility test) and an IELTS-like test. The data analysis was undertaken by making use of an error-based phonetic explication. The findings revealed that in terms of segmental performance, all of the participants had performed less intelligible pronunciation for distorting some consonants such as fricatives (dental, labio-dental, alveolar, and palatoalveolar), and vowels such as open vowels and close vowels. A phonemic analysis is vital for any English-speaking person such as common people, students, and teachers since the most prominent factor affecting pronunciation intelligibility is the misarticulation of segmental features (consonants and vowels).
\end{abstract}

Keywords: Intelligibility; Pronunciation; Phonetics; Segmentals. 


\section{PENDAHULUAN}

Tidak dapat disangkal bahwa pengucapan (pronunciation) yang sangat terkait dengan fonetik dan fonologi, secara singkat dapat didefinisikan sebagai studi tentang sistem suara, adalah salah satu keterampilan yang paling sulit dalam pembelajaran serta penguasaan bahasa Inggris (Aliaga-García, 2007; Martínez-Flor et al., 2006; \& Pourhosein-Gilakjani, 2016). Apa yang disebut dengan "inteligibilitas" telah berubah menjadi tujuan pengajaran pengucapan yang disepakati secara umum (Morley, 1991; Jenkins, 2006; Celce-Murcia et al., 2010; Brinton, 2012) sejumlah studi (misalnya, Timmis, 2002; Simon dan Taverniers, 2011; Tergujeff, 2013) menjelaskan bahwa banyak siswa bahasa Inggris masih menganggap pengucapan seperti penutur asli sebagai salah satu tujuan yang ideal.

Namun, ini juga menunjukkan bahwa model alternatif sering diadopsi sebagai alternatif yang lebih praktis dan dapat dicapai (Subtirelu, 2013). Dalam studi ini, penulis menunjukkan bahwa kejelasan adalah tujuan pengajaran pengucapan. Tergujeff (2013) mencatat bahwa mayoritas pelajar bahasa kedua dalam studinya "melaporkan kefasihan dan inteligibilitas atau kejelasan sebagai tujuan utama mereka dalam pengucapan bahasa Inggris". Namun, dia kemudian berkomentar bahwa setiap referensi yang dibuat peserta untuk pengucapan seperti penutur asli tampaknya merupakan "anganangan".

Demikian pula, Subtirelu (2013) menunjukkan bahwa dalam perjalanan penelitiannya, tujuan pelajar berubah dari waktu ke waktu dan dengan lebih banyak eksposur ke bahasa target, awalnya memilih untuk pengucapan seperti penutur asli dan kemudian untuk model alternatif. Namun, wawancara dalam penelitiannya menyoroti bahwa perubahan ini dihasilkan dari pesimisme tentang pencapaian tujuan mereka yang sebenarnya, daripada perubahan yang menentukan dari tujuan yang diinginkan.

Terlepas dari berbagai hasil pembelajaran yang diharapkan dan tujuan penguasaan pengucapan yang diminta oleh pelajar bahasa Inggris, guru mereka tetap menjadi tumpuan ekspektasi untuk merealisasikan tujuan tersebut. Guru adalah sumber kehidupan dan keberhasilan sekolah serta siswa (Robinson, 2018). Mereka pasti memiliki sejumlah peran penting di dalam kelas seperti, sebagai pengontrol, pembisik, sumber daya, penilai, penyelenggara, peserta, dan pengajar (Harmer, 2007). Oleh karena itu, hanya memiliki persepsi dan keyakinan positif tentang pentingnya pelafalan bahasa Inggris tidak akan cukup tanpa dukungan dari keterampilan dan penampilan pengucapan yang memadai.

Selain itu, peran guru sebagai narasumber, penilai, dan pembisik selalu menuntut seorang guru bahasa Inggris untuk berbicara bahasa Inggris yang dapat dimengerti yang diharapkan dapat sebebas mungkin dari kesalahan fonemik dan ketidaktepatan prosodi. Dengan kata lain, sebelum mengaktualisasikan tujuan siswa untuk mencapai pelafalan seperti penutur asli atau pelafalan yang dapat dimengerti, guru bahasa Inggris, dengan sendirinya, harus memiliki semua kriteria untuk diklaim sebagai penutur bahasa Inggris yang dapat dimengerti. Jika tidak, bukan tidak mungkin mereka akan berkontribusi pada kegagalan pembelajaran dan pemerolehan bahasa Inggris siswanya.

Istilah inteligibilitas yang digunakan dalam penelitian ini tidak hanya, seperti yang umumnya dikenal, sebagai sejauh mana katakata seseorang dapat dipahami atau dipahami oleh orang lain, di mana bias subjektif mungkin dapat terjadi. Sejalan dengan itu, kejelasan dilihat, dinilai dan dianalisis dari kinerja fonologis seperti performa segmental. Inilah yang membuat studi saat ini berbeda dari yang lain. Studi ini menggunakan PIT yang dirancang untuk tes kejelasan atau inteligibilitas pengucapan untuk mengukur dan mengeksplorasi kinerja dan penampilan pelafalan segmental dan suprasegmental guru bahasa Inggris non-native. Jadi, kejelasan pengucapan itu sendiri lebih ditentukan dengan melihat fitur pengucapan segmental yang umumnya terkait dengan kemampuan dalam artikulasi bunyi-bunyi konsonan maupun vocal (vowel). 


\section{METODE PENELITIAN}

Penelitian ini dilakukan dengan desain deskriptif kualitatif. Prinsip umum penelitian kualitatif dikembangkan secara induktif dari observasi spesifik ke generalisasi lebih luas atau yang disebut pendekatan bottom-up (Chapko et al., 2009). Kajian kualitatif biasanya dilakukan oleh seorang peneliti pada awalnya dengan melakukan beberapa langkah khusus, kemudian mendeteksi keteraturan dan pola, dan akhirnya berakhir dengan beberapa kesimpulan dan teori (Schartz, 2010; Derwing \& Munro, 2005). Tujuan utama dari penelitian deskriptifkualitatif adalah peringkasan yang komprehensif (Merriam, 2009). Oleh karena itu, desain deskriptif-kualitatif ini sangat cocok untuk penelitian saat ini karena penelitian saya berkaitan dengan penyelidikan fonetik yang berarti bahwa ada sejumlah pengukuran dan analisis khusus yang dilakukan untuk mengeksplorasi kinerja fonetik guru secara menyeluruh yang akhirnya berakhir pada beberapa kesimpulan. kejelasan pengucapan mereka.

Partisipan yang terlibat dalam penelitian ini adalah tiga orang staf pengajar yang bekerja di suatu lembaga bahasa dan ditugaskan untuk menangani kelas EPC (English Proficiency Class) setara dengan kelas bahasa inggris umum. Dalam mengumpulkan data, teknik pertama yang digunakan adalah apa yang disebutm PIT (Pronunciation Intelligibility Test) berfokus pada analisis kesalahan fonetik yang dilakukan si penutur untuk mengetahui seberapa jelas guru bahasa Inggris berbicara bahasa Inggris pada fitur segmentasi (consonants and vowels). Teknik pengumpulan data yang kedua adalah melalui tes IELTS.

Dalam menganalisis PIT dan IELTS, semua jawaban yang diucapkan oleh masingmasing peserta rekam. Rekaman kemudian ditranskripsikan secara leksikal dan fonemik. Baik penutur asli (native-speaker Examiner) bahasa Inggris dan saya mendengarkan dengan seksama setiap suara yang dihasilkan di bagian ini dan menganalisis berbasis metode dan kaidah-kaidah yang dipakai dalam analisis fonemik segmental.
Kemudian, keputusan dibuat bersama apakah sebagian besar suara yang dihasilkan oleh peserta dapat dipahami, kurang dapat dipahami, atau tidak dapat dipahami.

\section{HASIL DAN PEMBAHASAN}

\subsection{Hasil}

Tiga dari peserta diinstruksikan untuk membaca sejumlah kalimat dengan suara keras. Daftar kalimat dirancang oleh SzpyraKozlowska (2010) berdasarkan kata-kata yang paling sering salah diucapkan yang diucapkan oleh penutur bahasa Inggris non-penutur asli menengah atas hingga mahir, terlepas dari profesi mereka sebagai guru atau siswa. Saya telah mentranskripsikan setiap kalimat secara fonemik menjadi simbol fonemik sehubungan dengan pengucapan yang Diterima (RP) dan Pengucapan Umum Amerika (GR) untuk memfasilitasi saya dalam membandingkan pengucapan standar dengan data pengucapan yang diperoleh dari tiga guru pilihan tersebut. 


\begin{tabular}{|c|c|c|c|}
\hline \multicolumn{4}{|c|}{ Tabel 1. Hasil fonemik segmental dalam 10 kalimat terpilih } \\
\hline Kalimat & Peserta 1 & Peserta 2 & Peserta 3 \\
\hline $\begin{array}{l}\text { They had soup, } \\
\text { then steak with } \\
\text { lettuce and other } \\
\text { vegetables for } \\
\text { dinner. }\end{array}$ & $\begin{array}{l}\text { der hed soap, dein sterk wit letju:sen } \\
\text { ' } \Lambda \text { dəvedzetəbəlz. fo: 'dinə. }\end{array}$ & $\begin{array}{l}\text { deI həd sup, den sterk wit } \\
\text { 'letəs ənd ' } \Lambda \text { dər } \\
\text { 'veḑtəbəlzfestebel fər } \\
\text { 'dinər. }\end{array}$ & $\begin{array}{l}\text { deI həd sup, den } \\
\text { sterk wit 'letəs ənd } \\
\text { ' } \Lambda \text { dərfestebel fər } \\
\text { 'dinər. }\end{array}$ \\
\hline $\begin{array}{l}\text { They saw a dead } \\
\text { guinea pig in the } \\
\text { meadow near the } \\
\text { house opposite } \\
\text { ours. }\end{array}$ & 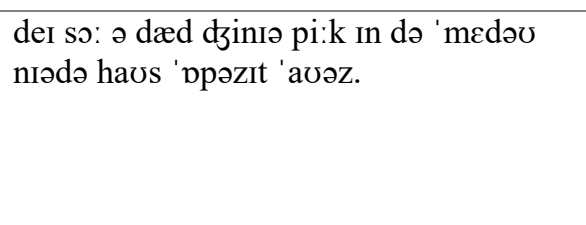 & 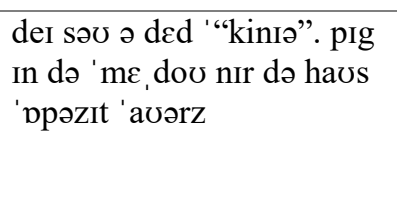 & $\begin{array}{l}\text { deI səu ə ded } \\
\text { '"kiniə". pig in də } \\
\text { 'me, dou nir də } \\
\text { havs ofosit 'auərz }\end{array}$ \\
\hline $\begin{array}{l}\text { Foreign tourists } \\
\text { don't like the } \\
\text { climate here. }\end{array}$ & ' forın 'tuərısts dəont laık ðə 'klaımıt hıə. & $\begin{array}{l}\text { 'forən 'turəsts dount laik } \\
\text { ðə 'klaimət hir }\end{array}$ & $\begin{array}{l}\text { 'forən 'turəsts } \\
\text { dount laik ðə } \\
\text { 'klaimət hir }\end{array}$ \\
\hline $\begin{array}{l}\text { A colonel and a } \\
\text { captain worked on } \\
\text { a radar. }\end{array}$ & $\begin{array}{l}\text { ə'kelenel” ænd ə 'kəpteIn w3:kt pn ə } \\
\text { 'reðə }\end{array}$ & $\begin{array}{l}\text { ə ' 'kelenel ənd ə 'kæptən } \\
\text { w3rkt an ə 'reI, dər }\end{array}$ & $\begin{array}{l}\text { ə 'kelenəl ənd ə } \\
\text { 'kæptən w3rkt an ə } \\
\text { 'reI, dər }\end{array}$ \\
\hline $\begin{array}{l}\text { They examined his } \\
\text { certificate and said } \\
\text { he wasn't capable } \\
\text { of writing the } \\
\text { preface to this } \\
\text { author's book. }\end{array}$ & 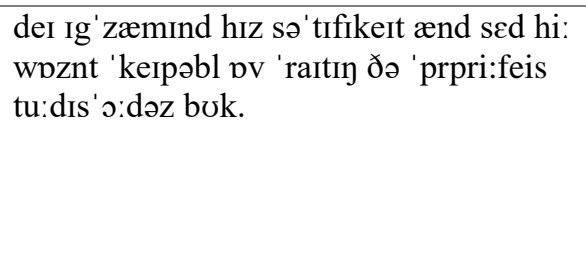 & $\begin{array}{l}\text { deI Ig' zæmənd Iz } \\
\text { sər' tıfikeit ənd sæd hi } \\
\text { 'wazənt 'keIpəbəl əv } \\
\text { 'raitıy də'pri:feis tə ðIs } \\
\text { 'odərz bok }\end{array}$ & $\begin{array}{l}\text { deI ig' zæmənd Iz } \\
\text { sər' tıfikət ənd sed } \\
\text { hi 'wazənt } \\
\text { 'keipəbəl əv 'raitıy } \\
\text { də 'prefəs } \\
\text { tədis' odərz bok }\end{array}$ \\
\hline $\begin{array}{l}\text { In this family one } \\
\text { brother is a } \\
\text { butcher, another is } \\
\text { a lawyer and their } \\
\text { sister is a nurse. }\end{array}$ & 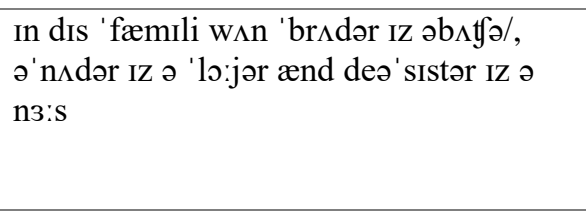 & 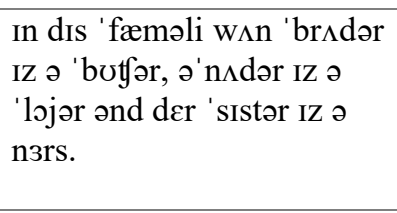 & 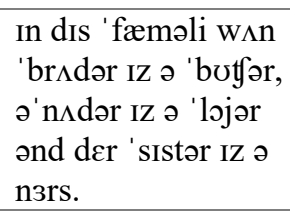 \\
\hline $\begin{array}{l}\text { Her favorite stars } \\
\text { are Elvis Presley, } \\
\text { Barbara Streisand, } \\
\text { Tina Turner and } \\
\text { Eddie Murphy. }\end{array}$ & $\begin{array}{l}\text { h3: 'fevərit sta:z a:r 'clvis 'prezlei, } \\
\text { 'ba:b(ə)rə 'straizənd, 'ti:nə 't3:nər } \\
\text { ænd'cdi 'ms:pi. }\end{array}$ & $\begin{array}{l}\text { hər 'feivərit starz ər 'clvis } \\
\text { 'preslei, 'barbərə strains } \Lambda \text { n } \\
\text { 'tinə 't3rnər ənd' } \varepsilon \text { di 'mзrfi. }\end{array}$ & $\begin{array}{l}\text { hər 'feivərit starz } \\
\text { ər 'elvis 'presli, } \\
\text { 'barbərəstr3slend, } \\
\text { 'tinə 't3rnər } \\
\text { ənd' } \varepsilon d i \text { 'm3rpi. }\end{array}$ \\
\hline $\begin{array}{l}\text { He says it isn't } \\
\text { comfortable to live } \\
\text { in this ancient } \\
\text { castle in the } \\
\text { mountains and } \\
\text { walk across that } \\
\text { damaged bridge } \\
\text { every day. }\end{array}$ & 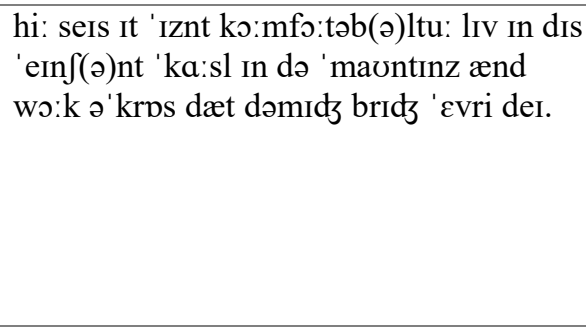 & 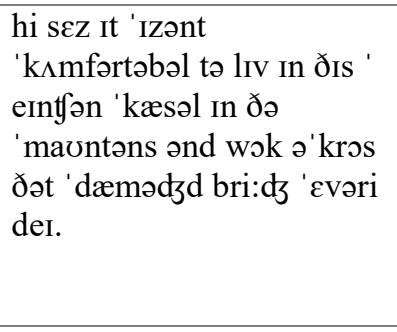 & 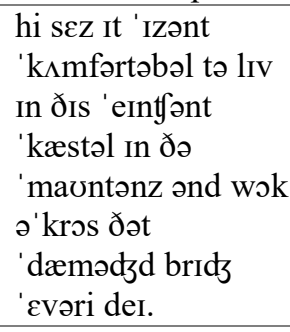 \\
\hline $\begin{array}{l}\text { Leonard felt sweat } \\
\text { on the surface of } \\
\text { all his body when } \\
\text { he saw that } \\
\text { dangerous wolf. }\end{array}$ & $\begin{array}{l}\text { leonəd felt swet pn ðə 's3:fis pv } ૭: 1 \text { hIz } \\
\text { 'bpdi wen hi: sə: ðæt 'deIndzrəs wolf. }\end{array}$ & $\begin{array}{l}\text { lenərd felt swet an ðə } \\
\text { 's3rfəs əv ol Iz 'badi wen } \\
\text { hi sə ðət 'deIndzərəs wolf. }\end{array}$ & $\begin{array}{l}\text { lenərd felt swet an } \\
\text { ðə 's3rfəs əv əl Iz } \\
\text { 'badi wen hi sə ðət } \\
\text { 'deIndzərəs wolf. }\end{array}$ \\
\hline $\begin{array}{l}\text { It occurred that } \\
\text { instead of going to } \\
\text { Turkey, we had to } \\
\text { go on separate } \\
\text { journey to another } \\
\text { country. }\end{array}$ & 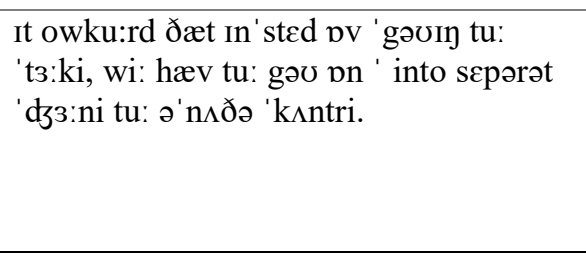 & 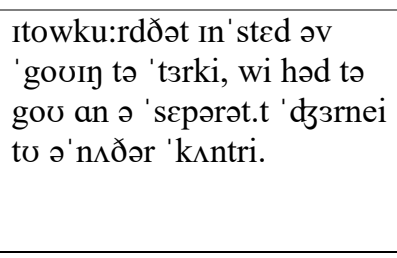 & 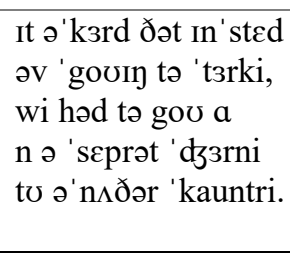 \\
\hline
\end{tabular}


Tabel 2. Hasil Leksion segmentasi

\begin{tabular}{|c|c|c|}
\hline Lexicons/phrases & Phonemic transcription & Participant's answers \\
\hline $\begin{array}{l}\text { urface climate } \\
\text { ancient favourite } \\
\text { steak climate } \\
\text { captain radar } \\
\text { (in search of } \\
\text { sound ei) }\end{array}$ & 's3:fis ' klaimıt' ein $\int(ə) n t$ ' fervəritsterk' klaimıt' kæptın ' reıdə & favorite, steak, radar, \\
\hline $\begin{array}{l}\text { said certificate } \\
\text { dangerous } \\
\text { comfortable } \\
\text { foreign Presley } \\
\text { damaged preface } \\
\text { (in search of ei) }\end{array}$ & $\begin{array}{l}\text { sed sə'tıfikıt 'deindzrəs 'k^mf(ə)təbl 'fprin 'prezli } \\
\text { 'dæmıdzd 'prefis }\end{array}$ & said \\
\hline $\begin{array}{l}\text { opposite examined } \\
\text { mountains } \\
\text { Streisand climate } \\
\text { said captain } \\
\text { (in search of } \\
\text { sound ai) }\end{array}$ & $\begin{array}{l}\text { 'ppəzit Ig' zæmınd 'mauntınz Straisend (straisaend) } \\
\text { 'klaimit scd 'kæptın }\end{array}$ & $\begin{array}{l}\text { Mountains, } \\
\text { Streisand, climate }\end{array}$ \\
\hline $\begin{array}{l}\text { instead sweat said } \\
\text { dead bead mead } \\
\text { head meat } \\
\text { (in search of } \\
\text { sound eor c) }\end{array}$ & In'sted swet sed ded bi:d mi:d hed mi:t & sweat, dead, head, said, \\
\hline $\begin{array}{l}\text { Turner Murphy } \\
\text { nurse worked } \\
\text { journey Turkey } \\
\text { colonel } \\
\text { (in search of 3:) }\end{array}$ & 't3:nə 'm3:fi nз:s w3:kt 'dz3:ni 't3:ki 'k3:nl & $\begin{array}{l}\text { Turner, murphy, nurse, work, } \\
\text { journey and colonel }\end{array}$ \\
\hline $\begin{array}{l}\text { guinea pig foreign } \\
\text { opposite Presley } \\
\text { favourite } \\
\text { in search of sound } \\
\text { I }\end{array}$ & 'gini pig 'fbrin 'ppəzit 'prezli 'fervərit & $\begin{array}{l}\text { Guinea } \\
\text { Pig } \\
\text { Foreign } \\
\text { Opposite } \\
\text { Favorite } \\
\text { Presley }\end{array}$ \\
\hline $\begin{array}{l}\text { colonel worked } \\
\text { castle walk } \\
\text { journey } \\
\text { in search of } \\
\text { silenced sound }\end{array}$ & $\begin{array}{l}\text { 'k3:nl w3:kt 'ka:sl wo:k 'dz3:ni } \\
\text { (l and } \mathrm{r} \text { are silenced) }\end{array}$ & $\begin{array}{l}\text { Colonel } \\
\text { Worked } \\
\text { Castle } \\
\text { Walk } \\
\text { Journey }\end{array}$ \\
\hline
\end{tabular}

Ket: Bagian yang ditebalkan atau yang digarisbawahi adalah distorsi segment (konsonan dan vocal) yang berubah dari bunyi yang seharusnya.

\subsection{Pembahasan}

Masalah fonemik pertama dan terpenting yang membuat distorsi terhadap inteligibilitas pengucapan semua peserta dalam studi ini berkaitan dengan frikatif dental $/ \theta /$ dan $/ ð /$. Sangat disayangkan bahwa semua guru yang berpartisipasi dalam penelitian saya ini gagal menggunakan kedua konsonan / $\theta$ / dan / ð /. Hampir setiap kata dan baris yang mengandung bunyi gigi tersebut tidak berhasil diartikulasi dengan baik, apalagi dengan sempurna. Masing- masing kedengarannya sulit mengartikulasikan kedua suara yang seharusnya mereka gunakan ujung lidah dan gigi atas untuk menghasilkan suara. Untuk mengartikulasikan / $\theta$ / dan / ১/, ujung lidah dijorokkan sedikit keluar dan harus membuat kontak ringan dengan bagian belakang atas (gigi depan), atau ujung lidah kita cenderung menonjol di antara gigi bawah dan atas . Kemudian, langitlangit lunak kita harus dinaikkan. Dalam hal cara artikulasinya, frikatif / $\theta$ / termasuk dalam apa yang disebut fortis (tidak bersuara) dan / $ð /$ bunyi diklasifikasikan sebagai lenis (bersuara). Singkatnya, sebuah lenis memang membutuhkan 
penggunaan pita suara untuk membuat suara khasnya (semacam getaran); sedangkan fortis tidak. Tidak diragukan lagi, ada banyak leksikon yang ada dalam bahasa Inggris yang mengandung frikatif gigi ini, biasanya ditandai dengan huruf 'th' yang dipasangkan seperti kata think, thank, bath, math, that, then, another, mother, dll. Huruf ' $t h$ ' pada kata tebal tersebut harus diartikulasikan dengan / $\theta$ / atau / $\partial /$.

Menurut saya, bagian yang sulit adalah untuk mencari tahu mana yang seharusnya / $\theta$ / dan mana yang harus / ð / di mana masalah ini lebih mengarah pada masalah cara artikulasi yang menangani bunyi konsonan fortis dan lenis. Namun, dalam hal tempat artikulasi, kedua bunyi tersebut dihasilkan oleh alat bicara yang sama persis. Menurut peneliti fonetik Gerald Kelly (2000), kesulitan dalam mengartikulasikan frikatif gigi telah ditemui oleh sejumlah orang yang menggunakan bahasa asli Arab, Cina, Prancis, Jerman, India, Italia, Jepang, Portugis, Rusia., Skandinavia dan Turki. Sebuah laporan penelitian telah disebarkan oleh seorang ahli fonetik Polandia bernama Andrzej Porzuczek yang menyatakan dalam studinya (2015) bahwa orang polandia membuat banyak kesalahan fonemik untuk mengartikulasikan suara gigi / $\theta$ / dan / ð /. Haruskah Indonesia termasuk negara yang dicantumkan oleh Kelly (2000)? adalah pertanyaan yang layak untuk diajukan.

Saya tidak menyangkal bahwa telah banyak penelitian fonetik yang membahas permasalahan yang dihadapi pembelajar bahasa Inggris Indonesia dalam menghadapi konsonan bahasa Inggris seperti Habibi (2016), Komariah (2016) dan Utami (2018). Sayangnya, studi tersebut hanya menyentuh permukaan dari kekhawatiran karena tes yang digunakan oleh para peneliti dirancang untuk melakukan elisitasi fonemik satu kali duduk. Untuk memastikan frikatif / $\theta$ / dan / ð / dikonfirmasikan sebagai kesalahan di seluruh negeri, serangkaian tes konsonan yang sangat komprehensif harus diadakan sebagai instrumen. Saya rasa masalah tentang produksi suara gigi / $\theta$ / dan / ð / harus segera diambil alih oleh pembelajar bahasa Inggris, apalagi guru bahasa Inggris untuk mendistorsi / $\theta /$ atau / $/$ menjadi konsonan t. Konsonan / $\theta$ / atau / $\mathrm{d} / \mathrm{dan} / \mathrm{t} / \mathrm{atau}$ / d / tidak sama, dan mereka berbagi tempat artikulasi yang berbeda serta cara artikulasi yang berbeda. Jika masalah seperti itu terus berlanjut dan memburuk, kejelasan seseorang akan terancam dan bahkan terancam karena ada banyak kata yang mirip dalam bentuk dengan kata-kata yang mengandung frikatif gigi $/ \theta /$ atau $/ ð /$. Akibatnya, miskomunikasi mungkin terjadi antara pembicara dan pendengarnya. Saya akan memberikan saran terbaik saya untuk masalah ini segera di bab berikutnya.

Selanjutnya ketidakjelasan pengucapan (unintelligible pronunciation) terjadi pada vokal terbuka / æ /, / $\Lambda /, /$ a: /, dan / $\mathrm{p} /$. Suara itu sering digunakan secara bergantian dalam penggunaan yang salah oleh semua peserta. Kata-kata yang mengandung vokal / æ / mengalami paling banyak kesalahan pengucapan. Tampaknya semua peserta mencoba mengakali vokal / æ / dengan mendistorsi vokal lain yang mungkin dan terkait erat seperti a: /, dan / $\mathrm{p}$ dan terkadang dengan suara vokal tengah / e /. Bunyi / æ / tidak diragukan lagi vocal ini sepertinya telah khas hanya dalam bahasa Inggris, sebagian besar bahasa di dunia tampaknya tidak memiliki bunyi ini (Kelly, 2000), termasuk bahasa asli ketiga peserta tersebut. Saya yakin inilah alasan mengapa begitu banyak orang mengubah bunyi vocal / æ / atau menggantinya dengan huruf hidup lain. Kelly (2000) menyebutkan daftar negara yang dilaporkan mengalami kesulitan memproduksi vokal tersebut seperti Arab, Cina, Prancis, Jerman, Yunani, India, Italia, Jepang, Portugis, Rusia, Skandinavia, Spanyol, dan Turki. Bahasa Indonesia mungkin harus masuk dalam daftar.

Secara pribadi, saya telah mengajar bahasa Inggris selama lebih dari satu dekade, dan saya perhatikan bahwa masalah semacam ini telah dihadapi oleh sebagian besar siswa saya. Selain itu, vokal / æ / telah menjadi kata-kata yang paling sering salah diucapkan dalam sebuah penelitian yang dilakukan oleh seorang profesor fonetik Sobkowiak (2001), dekade berikutnya terbukti benar dalam beberapa penelitian ilmiah lainnya (Zajac 2015). Dua tahun terakhir (2018), saya juga melakukan studi analitik ke kesalahan fonemik regional yang ditimbulkan dari bahasa Inggris beraksen regional yang diucapkan oleh guru bahasa Inggris terpilih. Temuan menunjukkan bahwa tiga guru bahasa Inggris nonnatif dari tiga provinsi berbeda di Indonesia memiliki masalah yang sama dalam mengartikulasikan vokal terbuka / æ /.

Secara fonetik, agar berhasil mengucapkan vokal / æ /, kita harus fokus pada posisi lidah dan rahang yang benar. Kita perlu membuka mulut selebar mungkin, lalu sedikit melebarkan bibir kita, dan menegangkannya. Kita harus menegangkan lidah kita, meratakannya, dan mendorongnya ke depan. Lidah kita harus ditempatkan sangat rendah di dalam mulut. Ujung lidah kita harus menyentuh bagian belakang gigi depan bawah kita. Perlu diingat bahwa bunyi / æ / adalah bunyi vokal yang sangat terbuka, jadi rahang kita harus sangat rendah dan lidah Anda harus sangat rata. Huruf vokal / æ / sebagian besar muncul pada huruf a yang berada di 
antara dua konsonan seperti back, bad, band, bank, bat, black, flat, hand, kebetulan, happy, land, man match, dll. Selain itu, dalam istilah dari satu fitur supra-segmental bernama tekanan leksikal suku kata, sebuah kata yang mengandung lebih dari dua suku kata memiliki suku kata tonik menjadi satu dengan / æ / vokal di dalamnya. Misalnya kata terjadi / 'hæpən /, happy / 'hæpi /, matter 'mætə, mengerti, ndə'stænd, value / 'vælju: /, dan banyak lagi.

Juga, karena berasal dari kata stres dan intonasi, kata-kata yang mengandung vokal / æ / biasanya menerima nada yang lebih kuat dibandingkan dengan suara vokal panjang lainnya yang tampaknya memiliki perlakuan yang sama seperti itu. Sekarang pertanyaannya adalah apakah perubahan vokal $æ$ dalam kata-kata menghalangi kejelasan pengucapan seseorang ?. Jawaban saya adalah ya, sebagian besar memang demikian, dan tidak, partai tidak. Hal ini kebanyakan terjadi karena terdistorsi dengan vokal yang menyimpang jauh seperti vokal / $\Lambda$ / dan yang diklasifikasikan sebagai vokal tengah. Tidak, pesta tidak akan dilakukan jika didistorsi oleh / a: / suara. Bunyi / a: / sebagian besar menggantikan vokal / æ / dalam pengucapan Inggris dan yang hampir mirip seperti bahasa Skotlandia, Welsh, dan Irlandia.

Selain itu, dalam praktek konteks nyata, saat saya mengubah vokal / æ / menjadi / a: / dalam pengucapan kata-kata seperti man / mæn /, back / bæk /, kekurangan / læk, dan seterusnya menjadi ma:n, ba:k, la:k dengan Teman-teman Amerika saya, semuanya mengerti kata itu diucapkan dengan sempurna. Salah satu dari mereka tidak perlu berkomentar bahwa saya berusaha terdengar seperti orang Inggris. Jadi, vokal terbuka / a: / akan menjadi alternatif teraman jika seseorang tidak berhasil menghasilkan vokal / æ / karena beberapa kekurangan, atau dia hanya malas mengartikulasikan organ pidatonya untuk menghasilkan suara.

Masalah berikutnya yang perlu dibahas lebih lanjut adalah apa yang disebut distorsi dan perubahan fonemik. Ini adalah kesalahan bersyarat di mana pembicara tidak menyadari bahwa sejumlah fonem telah diubah dengan sempurna dalam rendisi bunyi yang mereka produksi. Houghton (2003) mengatakan bahwa masalah ini terjadi karena sejumlah cacat artikulasi. Pertama, distorsi fonemik dari jenis substitusi, adalah bahwa satu fonem direplikasi untuk fonem lain. Misalnya, bunyi post-alveolar / w / diganti dengan aproksimasi semi vokal labiovelar / r / sehingga kata rabbit terdengar seperti wabbit. Kedua, distorsi fonemik akibat penghilangan bunyi adalah suatu fonem dalam sebuah kata dihilangkan misalnya bown ake untuk rake coklat.

Perlu dicatat bahwa distorsi fonemik akibat kelalaian suara tidak sama dengan istilah yang digunakan pada aspek-aspek wicara terkoneksi, yang disebut elision dan linking. Distorsi penghilangan cenderung mendistorsi fonem atau huruf penting dalam sebuah kata yang menyebabkan kejernihan ucapan seseorang menyusut dan menjadi kabur. Sementara itu, elision dan linking dianggap fitur prosodi yang meningkatkan dorongan ekstra dari penampilan pidato yang indah dan merdu. Terakhir, distorsi karena penambahan suara adalah bahwa suara tambahan ditambahkan ke dalam sebuah kata, misalnya seseorang mengucapkan buhlack horse sebagai pengganti black horse.

Guru bahasa Inggris yang berpartisipasi dalam penelitian saya ini kemungkinan besar pernah menghadapi distorsi tipe pertama di mana terlihat bahwa beberapa konsonan terdistorsi di sana-sini. Seperti frikatif / f / sering diartikulasikan sebagai plosif / p /, / $\theta$ / dan / ठ / sering terdistorsi dengan / $\mathrm{t} /$ atau / d /, velar / g / sekali diucapkan sebagai / $\mathrm{k}$ /, lenis frikatif / z / dibunyikan dalam fortis / s /, palate-alveolar / 3 / sering diperlakukan sebagai / $\int$ /, yang terakhir vokal terbuka / æ / terus-menerus terdistorsi baik sebagai / $\Lambda$ / atau / a: / atau / $\mathrm{p} /$ atau bahkan vokal tengah / e /.

Distorsi fonemik tersebut juga telah dilaporkan oleh sejumlah studi fonetik sebelumnya seperti jenis kesalahan ini benar-benar dapat menjadi ancaman yang merugikan kejelasan pengucapan seseorang karena tidak hanya berhasil mengaburkannya pada tingkat fonemik tetapi juga berpotensi merusak keseluruhan kata, frasa, dan klausa yang menyebabkan terjadinya miskomunikasi (Sobkowiak, 2001; WaniekKlimzack, 2001; Davis, 2008; Porzuczek, 2015; \& Zajac, 2015). Oleh karena itu, siapa pun yang memiliki kecenderungan untuk melakukan kesalahan ini tidak boleh menerima begitu saja. Jika terus berlanjut, akan sulit untuk diperbaiki.

Masalah selanjutnya yang ditemukan dari hasil performa dan rendisi fonetik kesalahan adalah pengucapan nama dalam bahasa Inggris. Nama bahasa Inggris yang digunakan dalam salah satu bagian dari tes PIT saya adalah Elvis Presley / ' $E$ lvis 'presli /, Barbara Streisand / 'barbərə 'straizənd /, Tina turner / 'tinə 't3rnər / dan Eddie Murphy / ' $\varepsilon d i$ 'msrfi /. Sejauh yang saya ketahui bahwa semua guru bahasa Inggris yang berpartisipasi dalam penelitian ini salah mengucapkan beberapa nama yang disebutkan di atas. Misalnya peserta pertama salah mengeja nama belakang Elvis Presley. Dia 
mengucapkannya / perslei / bukannya / prezli / menukar konsonan / r / dengan / e / dan mengubah vokal tunggal / I / menjadi diftong / ei /. Kemudian, Murphy, dalam suara $\mathrm{ph} / \mathrm{f} /$ diartikulasikan secara keliru. Huruf $\mathrm{p}$ dan $\mathrm{h}$ di Murphy seharusnya dilafalkan / f / bukan /p/. Sementara peserta kedua mengulang kesalahan pengucapan yang dilakukan pada nama belakang Presley / p3rslei / bukan / prezli / yang menukar konsonan / r / dengan / 3 / dan mengubah vokal tunggal / I / menjadi diftong / ei /. Adapun nama belakang Streisand. Daripada mengucapkannya / straizənd /, Tuan White melafalkannya / strains $\Lambda$ n /. Ada konsonan tambahan / $\mathrm{n} /$ dan mengubah suara schwa / a / menjadi / $\Lambda$ /. Lebih anehnya lagi, nama belakang 'Streisand' diucapkan / 'streslend / atau / streslænd / oleh peserta terakhir.

Masalah tipikal ini terjadi karena sejumlah faktor, salah satunya adalah apa yang disebut berlawanan dengan ejaan. Ini adalah suatu kondisi di mana pelafalan nama-nama bahasa Inggris tertentu tampaknya tidak sesuai dengan asosiasi ejaan atau pelafalan konvensionalnya, atau hanya karena nama yang lebih dikenal dengan ejaan serupa memiliki pengucapan yang sangat berbeda. Jenis yang terakhir ini disebut sebagai heterofon atau nama heterofonik yang berbeda dari heterograf, ditulis berbeda tetapi diucapkan dengan cara yang sama.

Mari kita lihat nama-nama Inggris seperti Geoffrey / 'dzefri /, Hugh / 'hju: /, Magdalene / 'mo:dlın /, Morgause / mo:r'gerz /, Seamus / ' Jerməs /, Zoe / zovi /, Vaughan / 'vo:n /, Phoebe / Isaac / 'Arzək /, Eithne / 'enjə /, Antawn / 'æntwa:n /, Michellie / mi'ki:li /, Buccleugh / bə'klu: /, Coke / 'kuk /, Colclough / 'korkli /, Dyches / 'darks /, Lalor / 'b: /, Mulər / 'b: / masih banyak lagi. Dalam mengucapkan nama-nama bahasa Inggris dan juga tempat bahasa Inggris dengan bantuan asosiasi fonemik latar belakang atau ejaan konvensional sehubungan dengan bagaimana sebagian besar merupakan leksikon bahasa Inggris yang diucapkan. Belajar bahasa Inggris sebagai bahasa kedua mungkin tidak memiliki banyak eksposur linguistik dalam hal sosio-budaya, dan latar belakang pengetahuan. Meskipun tinggal di negara berbahasa Inggris selama beberapa waktu, jenis kesalahan seperti itu masih mungkin terjadi.

Bagian terakhir yang harus dibahas dari hasil performa fonetik segmental adalah terkait dengan tidak dibunyikannya fonem bagian akhir. Fonem terakhir dalam kata-kata sering kali diabaikan karena penutur yang barangkali menganggapnya biasa. Sebagian besar akhiran yang sering diabaikan adalah berbentuk kata kerja terutama pada bentuk past-participle (diakhiri dengan bunyi / d /, / t /, atau / ed /), dalam s / es / (s / z / iz). Sedangkan untuk kelompok bunyi pertama / d /, / t /, atau / ed / sering kali digeneralisasikan menjadi hanya bunyi ed, sedangkan kelompok kedua bunyi penutup s / z / Iz sering digeneralisasikan hanya sebagai bunyi / s /. Apakah sebuah kata diakhiri dengan suara bersuara (z / iz) atau tidak tampaknya tidak mendapat perhatian sama sekali. Selain itu, akhiran terakhir / $\mathrm{k} /$ dan / $\mathrm{y} /$ sering salah diucapkan secara bergantian paling baik dicontohkan oleh kata benda dan pikir. Fonem akhir / $\mathrm{t} /$ juga begitu sering diabaikan, dan tetap tidak masuk akal seperti dalam surat bisu seperti pada kata tint, abduct, product, dan sebagainya.

Pertanyaannya adalah apakah masalah seperti itu mempengaruhi inteligibilitas seseorang, jawabannya adalah ya. Banyak fonem yang tidak terdengar dalam sebuah kalimat pasti akan merusak kejelasan pengucapan seseorang. Juga, masalah seperti itu tidak bisa begitu saja dikesampingkan. Fenomena ini pernah dikemukakan oleh Odlin (1989) sebagai pengaruh linguistik lintas budaya dalam hal identifikasi antarbahasa. Melihat masalah dari sudut pandang kurangnya latihan daripada faktor transfer bahasa seperti fonem akhir yang tidak beralasan terjadi karena beberapa orang tidak perlu untuk melakukannya. Alasannya adalah karena sebuah kata dibunyikan sebagai kata yang utuh, baru selesai. Misalnya, bantu negatif tidak sering diucapkan sebagai / doon / hanya tanpa fonem / t / di akhirnya. Beberapa orang mungkin menganggap bahwa satusatunya / doon / sudah cukup untuk membuat sebuah kata bekerja tanpa harus mengartikulasikan akhirannya / $\mathrm{t}$ / sama sekali. Hal ini juga didukung dengan pernyataan salah satu peserta saya yang mengaku tidak peduli suara ending tidak dibunyikan oleh semua siswa.

\section{KESIMPULAN}

Dari segi performa dan pengucapan dalam fitur-fitur segmental, penampilan fonologis peserta dianalisis dengan menggunakan serangkaian tes pelafalan. Hasil analisis segmental menunjukkan bahwa semua guru yang berpartisipasi tampaknya memiliki sejumlah kesalahan yang sama. Pertama mereka mengalami kesulitan untuk mengartikulasikan kata apapun yang mengandung frikatif dental / $\partial /$ dan $/ \theta /$, oleh karena itu kedua 
frikatif tersebut agak terdistorsi menjadi / $\mathrm{d} /$ atau / t / sounds. Kedua, masalah timbal balik mereka terletak pada vokal terbuka / æ, / / / /, a: /, dan / $\mathrm{p} /$ di mana vokal-vokal itu sering disalahgunakan secara bergantian, dan satu suara terkadang terdistorsi menjadi suara lain. Ketiga, mereka tampaknya tidak memperhatikan fonem terakhir dalam sebuah kata di mana bunyi akhir seperti bentuk past-participle atau past-participle (terdengar di / d / atau / id / / t /) paling sering diterjemahkan sebagai semata-mata / d /, kelompok kedua dari bunyi akhir s / z / Iz digeneralisasikan hanya sebagai bunyi / s /, ujung terakhir / $/$ dan / $/$ / sering salah diucapkan secara bergantian, fonem terakhir / $\mathrm{t} /$ juga sangat sering diabaikan, dan tetap tidak masuk akal seperti dalam surat bisu.

Kemudian, semua guru bahasa Inggris bukan penutur asli memiliki masalah besar dengan suku kata, sehingga banyak kata yang menerima lebih banyak suku kata yang dibutuhkan. Kelima, peserta secara keseluruhan tampak mengalami kesulitan dalam mengenali huruf bisu dalam katakata, sehingga banyak dijumpai huruf bisu (silent letters) yang tidak perlu dibunyikan. Keenam, masalah yang sama terjadi karena apa yang disebut kontraintuitif terhadap ejaan yang disebabkan oleh heteronim dalam sejumlah nama bahasa Inggris di mana para guru yang berpartisipasi secara salah menemukan beberapa nama bahasa Inggris untuk pengucapan mereka yang benar. Ketujuh, generalisasi fonemik yang berlebihan juga terjadi.

Terakhir, perubahan fonemik dan distorsi kadang-kadang ditemukan dalam pidato mereka di mana beberapa kata terdengar berbeda dari yang seharusnya karena terjadinya perubahan fonemik dalam kata-kata. Sejujurnya, sejauh ini, saya belum melihat kesalahan individu yang signifikan pada tingkat segmental karena semuanya secara mengejutkan berbagi masalah yang sangat mirip. Dengan kata lain, ketiga peserta memiliki inteligibilitas pengucapan bahasa inggris yang tidak memadai dalam segi segmentasi dikarenakan adanya sejumlah kesalahan yang bervariasi terkait fitur-fitur fonetik segmentasi. 


\section{DAFTAR PUSTAKA}

Aliaga-García, C. (2007). The role of phonetic training in L2 speech learning. Proceedings of the Phonetics Teaching and Learning Conference (PTLC2007), University College London. Available at http://www.phon.ucl.ac.uk/ptlc/ptlc2007_web_procindex.html.

Brinton, D.M. (2012). Pronunciation Instruction in Burns, A. and Richards, J.C. (eds.) The Cambridge Guide to Pedagogy and Practice in Second Language Teaching. Cambridge: Cambridge University Press, pp. 246-257

Celce-Murcia, M., Brinton, D.M. and Goodwin, J.M. (2010). Teaching pronunciation: A reference for teachers of English to speakers of other languages. New York: Cambridge University Press.

Chapko, M. K., Liu, C., Perkins, M., Li, Y., Fortney, J. C., \& Maciejewski, M. L. (2009). Equivalence of two healthcare costing methods: bottom-up and topdown. Health Economics, 18(10), pp. 1188-1201. doi: $10.1002 /$ hec. 1422

Davis, V. (2008). Contribution of error analysis to foreign language teaching. Mersin University Journal of the Faculty of Education. 2, 261-270.

Derwing, T. M., \& Munro, M. J. (2005). Second Language Accent and Pronunciation Teaching: A Research-Based Approach. TESOL Quarterly, 39(3), 379. DOI: 10.2307/3588486

Habibi, B. G. (2016). Phonetic errors in secondary students. Conaplin Journal, I(1), 56-69.

Harmer, J. (2007) The practice of English language teaching. 4th ed. Harlow: Pearson Education Limited.

Houghton, M. (2003). Pronunciation practice activities: A resource book for teaching English pronunciation. Cambridge: Cambridge University Press.

Jenkins, J. (2006). Global intelligibility and local diversity: possibility or paradox? In R.Rubdy, \& M. Saraceni (Eds.), English in the world. Global rules, global roles (pp. 32-39), London: Continuum.

Kelly, G. (2007). How to teach pronunciation. China: Pearson Longman.

Komariah, S. (2016). Leaning to speak with phonetics. The 61st TEFLIN Confrence (pp. 1142-1145). Surakarta: UNS Press.

Martínez-Flor, A., Usó-Juan, E., \& Alcón Soler, E. (2006). Towards acquiring communicative competence through speaking. In Usó-Juan, E., \& Martínez-Flor, A. (eds). Current Trends in the Development and Teaching of the Four Language Skills. Berlin: Mouton de Gruyter, 139-157.

Merriam. (2009). How to teach pronunciation in SLA contexts. Malaysia: Longman.

Morley, J. (1991). The Pronunciation component in teaching English to speakers of other languages. TESOL Quarterly, 25(3), pp. 481-520.

Odlin , G. (1989). Rhythm and vowel quality in accents of English. Research in Language, 2, 135-147.

Porzuczek, A. (2015). Handling global and local English pronunciation errors. In Waniek-Klimczak, E. \& Pawlak, M. (Eds.), Teaching and researching the pronunciation of English (pp. 169-187). New York: Springer.

Pourhosein-Gilakjani, A. (2016). A study on the situation of pronunciation instruction in ESL/EFL classrooms. Journal of Studies in Education, 1(1), 1-15.

Robinson, T. S. (2018). Approaches and methods in language teaching. Second edition. Cambridge: Cambridge University Press.

Schartz, G. (2010). Rhythm and Vowel Quality in Accents of English. Research in Language, 8. DOI 10.2478/v10015-010-0011-8.

Simon, J., \& Taverniers, S. (2011). Gathering on words in English pronunciation instruction. Research in Language, $8,169-155$.

Sobkowiak, W. (2001). English phonetics for Poles. Poznań: Wydawnictwo Poznańskie,

Subtirelu, N. (2013). 'What do learners want?: a re-examination of the issue of learner preferences regarding the use of 'native' speaker norms in English Language Teaching', Language Awareness, 22(3), pp. 270-291.

Szpyra-Kozlowska, J., \& Stasiak, S. (2010). From focus on words in English pronunciation instruction. Research in Language, 8, 163-177.

Tergujeff, E. (2013). Learner perspective on English pronunciation teaching in an EFL context. Research in Language, 11(1), pp. 81-95.

Timmis, I. (2002) Native speaker norms and International English. ELT Journal 56 (3), 240-249.

Utami, M. (2018). Developing a manual toward phomenics. Conaplin Journal, I(1), 56-69.

Waniek-Klimczak, E. (2001). Context for teaching English phonetics and phonology at Polish Universities and College: A survey. Teaching English phonetics and phonology II: Accent '97 (pp. 5-17). Lodz : Wydawnictwo Uniwersytetu Lodzkiego.

Zajac, M. (2015). Compiling a corpus-based list of words commonly mispronounced. In Waniek- Klimczak, E. \& Pawlak, M. (Eds.),Teaching and researching the pronunciation of English. (pp. 153-167). New York: Springe. 